\title{
İlişkisel ve Teknolojik Kaynakların E-Sadakat Üzerine Etkisi: Kamu ve Özel Banka Müşterileri Üzerinde Bir İnceleme (The Impact of Relational and Technological Resources on E-Loyalty: A Study on Public and Private Bank Customers)
}

\section{Hatice Elanur KAPLAN iD a}

a Niğde Ömer Halisdemir Üniversitesi, Niğde Sosyal Bilimler Meslek Yüksekokulu, Finans, Bankacılık ve Sigortacllık Bölümü, Niğde, Türkiye. haticeelanurkaplan@ohu.edu.tr

\begin{tabular}{|c|c|}
\hline MAKALE BİLGİSİ & ÖZET \\
\hline $\begin{array}{l}\text { Anahtar Kelimeler: } \\
\text { E-Sadakat }\end{array}$ & $\begin{array}{l}\text { Amaç - Bu araştırma; ilişkisel ve teknolojik kaynakların e-sadakat üzerindeki etkilerini özel ve kamu } \\
\text { banka çalışanları üzerinde incelemek amacıyla gerçekleştirilmiştir. }\end{array}$ \\
\hline $\begin{array}{l}\text { E-Hizmet Kalitesi } \\
\text { E-Memnuniyet }\end{array}$ & $\begin{array}{l}\text { Yöntem - Amaç doğrultusunda hazırlanan anket formu, } 2019 \text { yılı içerisinde Niğde il merkezinde } \\
\text { bulunan özel ve kamu bankalarından hizmet alan } 226 \text { ticari müşteriye uygulanmıştır. Ulaşılan veriler } \\
\text { bilgisayar ortamında analiz edilmiștir. İlişkisel ve teknolojik kaynaklar ile e-sadakat arasındaki ilisski }\end{array}$ \\
\hline Ticari Banka Müşterileri & $\begin{array}{l}\text { korelasyon analizi ile ilişkisel ve teknolojik kaynakların e-sadakat üzerindeki etkisi regresyon analizi } \\
\text { ile incelenmiştir. Ayrıca katılımcıların bankalarının hizmetlerine ilişkin algıladıkları çevrimdışı hizmet } \\
\text { kalitesi, e-hizmet kalitesi, e-hizmetlerden memnuniyet, güvenilirlik ve bağlllık (ilişkisel ve teknolojik }\end{array}$ \\
\hline $\begin{array}{l}\text { Gönderilme Tarihi } 6 \text { Aralık } \\
2019\end{array}$ & $\begin{array}{l}\text { kaynaklar) ile e- sadakat düzeylerinin hizmet aldıkları bankanın sahiplik durumuna göre (Özel ve } \\
\text { Kamu) farklılaşma durumu bağımsız gruplar t- testi ile incelenmiştir. }\end{array}$ \\
\hline $\begin{array}{l}\text { Revizyon Tarihi } 2 \text { Mayıs } \\
2020 \\
\text { Kabul Tarihi } 5 \text { Mayıs } 2020\end{array}$ & $\begin{array}{l}\text { Bulgular - Yapılan korelasyon analizi sonucunda, e-sadakat ile iliş̧isel ve teknolojik kaynaklar e- } \\
\text { (çevrimdışı hizmet kalitesi, e-hizmet kalitesi, e-memnuniyet, güvenilirlik ve bağlllık) arasında yüksek } \\
\text { düzeyde pozitif yönlü 0,01 düzeyinde karşllıklı anlamlı ilişkiler olduğu saptanmıştır. ìlişkisel ve } \\
\text { teknolojik kaynakların e-sadakat üzerindeki etkisini belirlemeye yönelik kurulan regresyon modelinin } \\
\text { anlamlı olduğu saptanmıştır. Araştırmada ayrıca kamu veya özel bankalardan hizmet alan } \\
\text { müşterilerin bankaların ilişkisel ve teknolojik kaynaklarına ilişkin algılarının ve e-sadakat } \\
\text { düzeylerinin istatistiksel olarak farklılık göstermediği, saptanmıştır. }\end{array}$ \\
\hline Araştırma Makalesi & $\begin{array}{l}\text { Tartışma - İlişkisel ve teknolojik kaynaklardan çevrimdışı hizmet kalitesi, e-memnuniyet ve bağlılığın } \\
\text { e-sadakati olumlu düzeyde etkileyerek artırdığı, e-hizmet kalitesi ve güvenilirliğin ise e-sadakat } \\
\text { üzerinde etkisinin olmadığı sonucuna ulaşılmıştır. Bu sonucun ortaya çıkmasında birbirine yakın olan } \\
\text { bu değişkenlerin ayrı ayrı ele alınmasını etkisinin olduğu düşünülmektedir. Çünkü bütünsel olarak } \\
\text { bakıldığında, ilişkisel ve teknolojik kaynakların müşteri sadakatini \%95 düzeyinde açıkladığ1 } \\
\text { saptanmıştır. }\end{array}$ \\
\hline
\end{tabular}

\begin{tabular}{ll}
\hline ARTICLE INFO & ABSTRACT \\
\hline Keywords: & $\begin{array}{l}\text { Purpose - This research; The aim of the study was to investigate the effects of relational and } \\
\text { technological resources on e-loyalty among private and public bank employees. }\end{array}$ \\
E-Loyalty & $\begin{array}{l}\text { Design/methodology/approach - The questionnaire prepared in line with the objective was applied to 226 } \\
\text { commercial customers receiving service from private and public banks in Niğde city center in 2019. The data } \\
\text { obtained were analyzed in computer environment. The relationship between relational and technological } \\
\text { resources and e-loyalty was analyzed by correlation analysis and the effect of relational and technological } \\
\text { E-Satisfaction }\end{array}$ \\
resources on e-loyalty was analyzed by regression analysis. In addition, the perceived level of offline service \\
quality, e-service quality, satisfaction from e-services, reliability and loyalty (relational and technological
\end{tabular}




\section{Giriş}

Günümüz pazar koşullarında, müşterileri elde tutmak işletmelerin varlıklarını sürdürebilmeleri açısından büyük önem taşımaktadır. Önceleri işletmeler ürün odaklı düşünerek, ürettikleri ürünler ile rakiplerinden farklılaşabilirken; günümüz artan rekabet ve ileri teknolojik imkânlar sayesinde işletmelerin ürünleri giderek birbirine benzemekte ve bu yüzden işletmeler kendilerini rakiplerinden farklılaştırmakta zorlanmaktadırlar. Günümüz rekabet ortamında farklı işletmeler benzer nitelik ve kalitedeki ürün ve hizmetlerini benzer düzeyde fiyatlara sattıkları için ürün, hizmet ve fiyat ile rekabet yapılmamaktadır. İşletmelerden farklılaşmanın tek yolu, sunulan hizmetlerin müşteri beklentilerine yanıt vermesi ve müşteri memnuniyetinin sağlanmasıdır (Nasır ve Nasır 2008: 237). Böylelikle işletmeye sadık müşteriler oluşturulabilir.

21. yüzyılda teknolojik anlamda olağanüstü gelişmeler kaydedilmiştir. Bu gelişmelerin en önemlisinin internet olduğu söylenebilir. İnternet sayesinde uzaklar yakın olmuş, iletişim çevrimiçi hale dönüşmüştür. Yaşanan bu değişim sosyal ve ekonomik yaşama yansıyarak, işletmelerin ürün ve hizmetlerinin elektronik ortama taşınmasına neden olmuştur. Bu gelişmeler, pazarlamacılara ve e-ticareti benimseyenlere yeni ve geniş fırsatlar ortaya çıkarmıştır. İnteraktif ortam, işletmecilere çevrimiçi satın alma davranışının etkinliğini artırmak için ürün ve hizmetleri hakkında detaylı bilgiler sunabilme olanağı sağlamakta, müşterilere ise araştırma maliyetini azaltarak zaman avantajı sağlamaktadır. Bu bağlamda geleneksel alışveriş ile çevrimiçi alışveriş arasında teknoloji temelinde önemli farklılıklar ortaya çıkmaktadır. Bu farklılıklar ise müşterilerin istek ve beklentilerinde değişimlere neden olarak sonuçlar açısından farklılıklar gösterebilmektedir (Demirgüneş, 2016:247). Akıllı telefonlar, e-postalar, internet tabanlı gerçekleştirilen yazılı ve görüntülü iletişim, etkileşimli uygulamalar içeren mobil cihazlar vb. birçok yenilik gerçek dünyadan sanal dünyaya doğru olan akışı hızla artırmaktadır. Sanal dünyaya doğru gerçekleştirilen bu akış bireylerin ve işletmelerin de ticari hayata olan bakış açısını ve katılımlarını değiştirmektedir (Faiz, 2018: 1676).

Yaşanan teknolojik gelişim ve değişimlerin en çok etkilediği sektörlerden birisi de bankacıllk sektörüdür. İnternetin yaygınlaşarak kullanıcı sayısının artması, bankaların ürün ve hizmetlerini elektronik ortama taşımasında etken olmuştur. Bankacıllk alanında yaşanan gelişmelerin bankaların ilişkisel ve teknolojik kaynakları kullanımlarına yön verdiği ve bankaların mevcut uygulamalarını geliştirerek yeni teknolojilere uyum sağlamaya çalıştıkları gözlenmektedir. Günümüzde hemen tüm bankaların internet bankacılığı şubeleri bulunurken, mobil uygulamalarla akıllı telefonlar aracılığıyla bankacılık işlemlerini yapmak daha da kolaylaşmıştır. Müşteriler diledikleri anda yedi gün yirmi dört saat bankalarına ulaşabilmekte ve bankalarının izin verdiği işlemleri şubeye gitmeden gerçekleştirebilmektedirler. Elektronik ortamda bankaların verdikleri ürün ve hizmetlerde ciddi bir rekabet içerisinde oldukları gözlenmektedir. Tüm bu gelişmelerin bankaların sunduğu elektronik hizmetlerin müşterilerin e-sadakat düzeylerine etki edeceği, daha iyi ürün ve hizmet sunan bankaların bu rekabetten yeni müşteriler kazanarak çıkacağı, rekabette geri planda olan bankaların ise mevcut müşterilerini rakiplerine kaptırarak, müşterileri tarafından sadakatsizliğe uğrayabileceği düşüncesiyle bu araştırma planlanmıştır.

Bu doğrultuda araştırmanın amacı; ilişkisel ve teknolojik kaynakların e-sadakat üzerindeki etkisini kamu ve özel banka müşterileri özelinde incelemektir. Araştırmada öncelikle e-sadakat olgusuna yer verilmekte, ardından e-sadakat üzerinde etkisi olabilecek başlıca ilişkisel ve teknolojik kaynaklardan bahsedilmektedir. Ardından buraya kadar açıklanan bilgilerin daha somut hale getirmek için kamu ve özel banka çalışanları üzerinde gerçekleştirilen bir uygulamaya yer verilmektedir.

\section{Kavramsal Çerçeve}

\subsection{E-sadakat}

İşletmelerin varlıklarını sürdürmeleri ve rakipleri karşısında rekabet üstünlüğü sağlamanın zorlaştığı, teknolojik bir devrimin yaşandığı günümüz şartlarında her işletme sadık müşteri kitlesine sahip olmayı istemektedir. Sadık müşterilere sahip olabilmek, işletmeler için vazgeçilmez bir unsurdur. Müşteri sadakatinin sağlanması elektronik ortamda geleneksel ortamlara kıyasla daha yoğun bir çaba ve mesai gerektirmektedir. Elektronik ortamların sunduğu zaman, mekân sınırı olmaksızın hizmet verebilme özelliği artık her işletme için sağlanabilecek bir unsur olmuştur. Bu da sanal ortamda müşterilerin daha fazla seçenekle karşılaşmasını ve değerlendirmesini akabinde satın alma sonrasında da tatmin/tatminsizliklerini yine benzer ortamlardan herkesin görebileceği şekilde sunabilme şansı vermiştir. Avantaj gibi görünen tüm bu kolaylıklar ve özellikler 


\section{H. E. Kaplan 12/2 (2020) 1334-1346}

ise işletmeler açısından elektronik ortamda müşteri tatmini sağlayarak müşterileri sadık hale getirmeyi zorlaştırmaktadır (Faiz, 2018: 1678).

E-sadakat kavramı gelişen teknoloji ve elektronik alışverişin sosyal ve ekonomik yaşamın içine girmesiyle birlikte 2000'li yıllardan sonra tartışılmaya ve kavramsallaştırılmaya başlanan bir kavramdır. E- sadakat kavramı için literatürde farklı yaklaşımlar bulunmaktadır. Geleneksel sadakat anlayışında müşterilerin tekrarlayan satın alma davranışlarını göstermesi sadakatin oluşması için gerekliliktir, bu durum e-sadakat içinde geçerli olup, farklılık yapılan satın almanın elektronik ortamda gerçekleşmiş olmasıdır. Bazı araştırmacılar ise bu durumu e-sadakati açıklamada yetersiz bularak işletmeden ürün veya hizmet satın alan kişilerin sonrasında işletmeye ait olan web sitesini incelemesi ve tekrardan aynı işletmeden ürün veya hizmet satın alması olarak belirtmişlerdir (Arslan ve Atalık, 2016: 3).

E-sadakat kavramı, müşterilerin elektronik ortamda tekrarlayan satın alma davranışı sergilemesi ve sunulan hizmetlere karşı olumlu tutum neticesinde bağlılık göstermesi şeklinde ifade edilebilir (Toufaily, Ricard ve Perrien, 2013). Sadık müşterilerin, sadık olmayan müşterilere nazaran işletmenin web sitesini daha çok ziyaret ettiği ve çevresine web site hakkında olumlu görüşler bildirmeye meyilli olduğu söylenebilir (Pratminingsih, Lipuringtyas ve Rimenta, 2013:105).

E-sadakat olgusu işletmelere önemli avantajlar sağlamaktadır. E-sadakat işletmelerin çapraz satışlarını artmakta böylelikle müşteri karlılığı ve müssterilerin yeniden satın alma davranışını tetikleyerek, işletme gelirlerinin artmasını sağlamaktadır (Toufaily, Ricard ve Perrien, 2013: 1443). Ancak e-sadakati sağlamak geleneksel müşteri sadakatını sağlamaya nazaran daha güçtür. Çevrimiçi ortamlarda müşterilerin çok fazla sayıda ürün ve hizmetlerin alternatiflerini bulabilmeleri, değiştirme maliyetlerinin cüzi oranda olması, işletme ve online mağazalar hakkında bilgi edinmenin geleneksel alışverişe göre daha kolay ve az zaman alması vb. unsurlar çevrimiçi ortamda sadakati sağlamayı güçleştirmektedir (Ltifi ve Gharbi, 2012: 5).

Günümüzdeki işletmelerde hizmet kullanıcıları ve müşterilerin tatmini ve sadakati sektörde sürekliliğin son derece önemli bir parçası olarak görülmekte, evrensel rekabet koşullarındaki yegâne amaç da kullanıcılar ve müşteri memnuniyetinin, sadakate dönüştürülmesidir. İşletmelerin, yüksek müşteri tatmini kazanmadan müşteri sadakati elde etmesi son derece güçtür. Hizmet kullanıcıları ve müşterilerin sadakati ve tatmini, onların gereksinim ve beklentilerinin doğru saptanması ve karşılanabilmesiyle mümkün olabilmektedir (Kotler ve Armstrong, 2012: 654).

Müşteri memnuniyeti, müşterilerin beklentileri ile işletmelerin sundukları ürün ve hizmetlerin ne derece örtüştüğü ile ilgilenirken; müşteri sadakati, müşterilerin duygusal bağ ile işletmelere bağlanmaya ne kadar istekli oldukları ve yeniden satın alma davranışı gösterip göstermeyecekleriyle ilgilenmektedir (Demir, 2012:682).

\section{2. İlişkisel ve Teknolojik Kaynaklar}

Günümüzde işletmeler, birbirilerine benzeyen ürün ve hizmetler sunan rakipler arasında tercih edilebilmek için müşterileri ile ilişkilerini güçlendirmekte ve bu doğrultuda müşterilerini elde tutarak sadık müşteriler elde etmeye çalışmaktadırlar. İşletmelerin genel olarak insan kaynakları ile müşterileri arasında kurulan iletişim ilişkisel olarak değerlendirilebilirken, günümüzde yaşanan gelişmeler bu ilişkide teknolojiye odaklanmış durumdadır. Çünkü önceden müşterilerle kurulan karşılıklı iletişim, elektronik anlamda yaşanan gelişmelerle yerini anlık çevrimiçi mesajlaşmalara, maillere vb. uygulamalara bırakarak, yüzyüze iletişimi sınırlandırmıştır.

İşletmelerin müşterileri ile kurduğu iletişimde, ilişkisel ve teknolojik kaynaklar zaman zaman birbiriyle birlikte, zaman zaman da birbirlerinden ayrı olarak hizmetlerin sunumunda yer almaktadır. Örneğin elektronik olarak hizmet alan bir müşteri satın alma işlemleri sırasında teknolojik olarak işletmenin sitesinden faydalanırken, ilişkisel olarak da sitede açılan bir iletişim penceresi veya telefonla işletmenin çalışanıyla bağlantı kurabilmektedir. Bu ve benzeri işlemler birlikte olabileceği gibi birbirinden bağımsız olarak da gerçekleştirilebilmektedir. İşletmelerin içerisinde bulundukları sektörlere ve sektörün yapısına ve müşteri kitlelerine göre kullanacakları ilişkisel ve teknolojik kaynaklar farklılık gösterebilecektir.

Bankacılık sektöründe müşteri sadakati oluşturmada etkili olabilecek ilişkisel ve teknolojik kaynakları, Kingshott, Sharma ve Chung (2018) çevrimdışı hizmet kalitesi, e-hizmet kalitesi, e-hizmetlerden memnuniyet, 


\section{H. E. Kaplan 12/2 (2020) 1334-1346}

güvenilirlik ve bağlılık olarak ele almışlardır. Aşağıda adı geçen ilişkisel ve teknolojik kaynaklar açıklanmaktadır.

Çevrimdışı hizmet kalitesi: Hizmet sektörünün ekonomi içerisindeki ağırlığının artması, ürün ve hizmetlerin üretilmesindeki yöntem farklılıkları, hizmet kalitesi konusunun önemini artırmıştır. İşletmelerin yoğun rekabet baskısı altında olduğu günümüz koşullarında varlıklarını sürdürebilmeleri ancak kaliteli hizmet sunmalarıyla gerçekleşebilmektedir. Hizmet kalitesi, "verilen hizmetin müşteri beklentisinin ne kadarın karşılayabildiğinin bir ölçüsü olarak" (Nasır ve Nasır, 2008: 241) tanımlandığı gibi müşterinin hizmeti almadan önceki beklentisinin hizmeti aldıktan sonra karşılanmasına ilişkin yaptığı karşılaştırma sonucu oluşan alg1 olarak tanımlanmıştır (Parasuraman, Zeithaml ve Malhotra, 2005:214). Daha geniş bir anlatımla, hizmet kalitesi müşterilerin beklentilerinin karşılanması hatta beklentilerinin ötesine geçmesi, alınan hizmete ilişkin müşterilerin algıladıkları kalite düzeyidir (Öztürk, 2013:66-67). Bundan dolayı verilen hizmetin müşteriyi tatmin etme düzeyi ya da ortaya koyduğu performans düzeyi hizmet kalitesi olarak ifade edilmektedir (Devebakan ve Aksarayl1, 2003: 40).

Geleneksel alışverişlerde, memnuniyet ve hizmet kalitesi kavramlarına etki eden özelliklerin araştırıldığ sayıda çalışma yapılmıştır (Giese ve Cote, 2002; Zeithaml 2000) İnternet üzerinden alışverişte ise memnuniyet ve hizmet kalitesi kavramlarına etki eden özelliklerin araştırıldığ oranla az sayıda olsa da önemi farkına varılan bu alandaki araştırmalar gün geçtikçe artmaktadır.

Bankaların sundukları ürün ve hizmetlerle ilgili olarak çevrimiçi hizmet kalitesi ele alındığında, banka şubeleri tarafından müşterilere sunulan ürünlerin avantajlarının yanında, verdikleri hizmetin hızı, niteliği, güvenirliği ile birlikte hizmet sunan banka personelinin iletişiminin müşterilerin bankanın verdiği hizmetlerin kalitesine ilişkin algılarında ön plana çıkan unsurlar olduğu söylenebilir. Müşterilerin bankacılık hizmetlerine ilişkin algıladıkları hizmet kalitesi bankalarına olan sadakatlerini etkileyebileceği gibi e-sadakatlerini de etkileyebilir.

E- hizmet kalitesi: Son zamanlarda internet üzerinden sadece kaliteli veya uygun fiyata ürün satmak yeterli değildir. Hizmet kalitesini artırarak müşterilerin her geçen gün değişmekte olan beklentilerine cevap verilme imkânı sağlanmalıdır. Online müşterilerin yüz yüze iletişimde bulunduğu satış elemanı değil bir ekrandır. Bu nedenle farklı internet sitelerinde dolaşan tüketicilerin ilgisini çekmek ve korumak kolay değildir. Online ortamda, incelenen ürün ve hizmetler, özellikler ve fiyatlar açısından kolay bir şekilde karşılaştırılmaktadır, bu nedenle de müşteriler açısından e-hizmet kalitesi anahtar bir kavram haline gelmektedir (Lee ve Lin, 2005:161).

İşletmelerin e-imalattan e-hizmete kadar faaliyetlerini oluşturduğu sektörlerinde, hizmet alanlar ile hizmet verenler arasında self-servis hizmet sürecindeki etkileşim e-hizmet olarak tanımlanmaktadır (Başaran ve Çelik, 2008: 49). E-hizmet kalitesi ise, e-hizmetlerin satın alınma işleminden dağıtılmasına kadarki süreçte işletmenin etkili mağazacılık uygulamalarını ve web sitesinin verimliliğini içeren, etkin bir pazarlama aracı olarak ele alınmaktadır (Parasuraman vd,. 2005). E-hizmet kalitesi müşterilerin çevrimiçi alışverişe dair teknik ve fonksiyonel açıdan memnuniyetlerini belirleyen önemli faktörlerden birisidir (Chinomona, Masinge ve Sandada, 2014).

Bankacılık hizmetleri açısından e-hizmet kalitesi ele alındığında, bankaların internet ortamında bilgisayar, tablet veya mobil uygulamalarla müşterilerine sundukları hizmetlerin niteliğine ilişkin müşteri algıları olduğu ifade edilebilir. Bu noktada sunulan hizmetlerin kesintisiz, hızlı ve kolay anlaşılabilir olması ön plana çımaktadır. Diğer bir önemli unsur ise elektronik ortamda sunulan hizmetlerin çeşitliliğidir. Bankaya gitmeden ihtiyaç duyulan hizmetlerin internet aracılığıyla hızlı ve kolay bir şekilde yapılabilmesi müşterilerin bankalarına duydukları e-sadakat üzerinde olumlu etkisinin olabileceği gibi, her işlemin yapılamaması, istenilen hızda ve işlevsel olmaması ise müşterilerin e-sadakatlerini olumsuz etkileyebilecektir.

E-hizmetlerden memnuniyet: Müşteri memnuniyeti günümüzde, işletmelerin önemini daha iyi anlayıp üzerinde durduğu bir kavramdır. Müşteri odaklı olmak, işletmenin müşteri ve piyasayı zemin alarak hareket etmesini de beraberinde getirmektedir. Müşteri memnuniyetinin yüksek olması, işletmenin kalıcılığını sağlamaktadır. Genel anlamda müşteri memnuniyeti, müşterilerin aldıkları ürün ve hizmetten duydukları hoşnutluğu ifade etmektedir. Daha kapsamlı bir ifade ise müşteri memnuniyeti, ürün veya hizmetin herhangi bir niteliğinden 


\section{H. E. Kaplan 12/2 (2020) 1334-1346}

ya da tamamından sağlanan veya sağlanamayan hoşnutluk düzeyini kapsayan, tüketimin getirdiği tatmine bağlı ulaşılan nihai sonuçtur (Duman, 2003: 45-46).

Her alanda yaşanan ileri teknolojik gelişmeler hizmet sektöründe de kendini göstermiş ve birçok hizmetin elektronik ortamda tüketiciye $7 / 24$, hızlı ve düşük maliyetli şekilde sunulmasını sağlamıştır. Elektronik ortamda sunulan hizmetlerin varlığı da literatürde e-memnuniyet kavramının tanımlanması gerekliliğini doğurmuştur (Bayram ve Şahbaz, 2017: 62). E-memnuniyet, tüketicilerin elektronik ortamda aldıkları ürün ve hizmetlerin beklentilerini karşılaması ve gelecekte aynı işletmeyi tekrar tercih etmesi olarak tanımlanmaktadır (Bayram ve Şahbaz, 2017: 62).

İşletmelerin sundukları ürün ve hizmetlerini gelişen bilgi iletişim teknolojileri sayesinde çevrimiçi ortama taşınması, müşteri memnuniyeti olgusunu da bu çerçevede e-memnuniyet olarak ele alınmasını getirmiştir. $\mathrm{Bu}$ nedenle de son yıllarda pazarlama alanında e-memnuniyet kavramı araştırma konusu olarak ilgi görmektedir. Müşteri memnuniyeti sunulan ürün veya hizmetin ister geleneksel ortamda isterse elektronik ortamda olsun tüm işletmeler açısından önem arz etmektedir. Ancak çevrimiçi ortamda memnuniyeti oluşturan faktörler geleneksel ortama göre farkl1lıklar göstermektedir. Geleneksel alışverişte müşteri memnuniyeti; fiziksel unsurlar, ürün ve hizmetin kalitesi, işletme personeli, hizmet verilen ortam vb. faktörlerden etkilenirken, çevrimiçi ortamda müşteri memnuniyetini; öncelikle işletmenin web sitesinin dizaynı, içeriği, güvenirliği, yine satılan ürün veya hizmetin kalitesi ön plana çıkmaktadır. E-memnuniyet çevrimiçi alışveriş sunan işletmenin gerek internet altyapısıyla gerekse sattı̆̆ı ürün ve hizmetlerin kalitesiyle müşterilerin beklentisini karşılaması ve müşterilerin memnun olarak ayrılmasıyla sağlanabilir (Yapraklı ve Yilmaz, 2008:141).

Özellikle bankacılık sektöründe çalışanların yoğun iş yükleri ve yaptıkları rutin işlemler verilen hizmetlerin hızını düşürmekte ve müşterilerin bankada uzun süre kalmalarına neden olmaktadır. Bu durum müşteri memnuniyetini olumsuz etkilemektedir. Çevrimiçi ortamda ise müşterilerin bankacılık işlemlerini kendilerini kısa sürede ve uygun maliyetle gerçekleştirmeleri neden olurken, banka personelinin yoğun işyükü nedeniyle yaptıkları hatayı sıfıra indirmektedir (Mikhaylichenko, 2015: 7-8). Bu durum da müşteri memnuniyetine olumlu olarak yansımaktadır.

Güvenilirlik: Güven kavramı üzerine psikolojiden ekonomiye, sosyolojiden işletmeye kadar çeşitli disiplinlerde birçok çalışma yapılmıştır. Farklı disiplinlerin güven kavramına bakış açıları da farklıdır. Ancak bu bakış açılarının ortak noktası güvenin insan ilişkilerinde olan önemi, ilişkileri yönlendirmesi ve davranışları üzerindeki etkileridir (Sağlam Arı \& Tunçay, 2010: 117). Pazarlama açısından güven konusuna değinildiğinde, ürün veya hizmeti alan tüketici ile ona ürün veya hizmeti sunan işletme arasındaki ilişkideki güvenden bahsedilmektedir. İşletme ile tüketici arasındaki ilişkinin, herhangi bir ilişkiden farklı olmadığı ve bu ilişkinin, tüketicinin o ürünü satın alıp almamasını etkilediği belirtilmektedir (Fournier, 1998:343).

Günümüzde yaşanmakta olan yoğun rekabet sebebi ile müşterilerin işletmeye duydukları güven ilişkisi geçmişe kıyasla daha önemli bir hal almıştır. Müşteri ile işletme arasındaki ilişkiyle doğru orantılı olarak müşteriler kişisel ve gizli bilgilerini firma ile paylaşabilir duruma gelmiştir ve aralarındaki bu ilişkinin derecesi arttıkça da paylaşım artmaktadır (Eren ve Erge, 2012:4455). Bir işletmeye güvenen müşteriler yapılan vaatlerin reklamlarda belirtildiği şekilde gerçekleştirileceğine ve işletmenin onların çıkarları için çalışacağına inanırlar (Nguyen, Leclerc ve Leblanc, 2013:96). Bu nedenle güçlü bir işletme, tüketici için güvenli bir ortam oluşturmaktadır çünkü beklentileri anlamakta, tüketim ve alım ile ilgili riskleri algılamakta ve müşterinin isteklerinin karşılanmasına yardımcı olmaktadır. Hizmetlerin saydamlığı işletmeleri tüketici için güvenli bir bölge ve cazip bir teklif haline getirmektedir (Berry, 2000:128). İşletmelerin müşteri çıkarlarını gözeterek, söylemlerinde dürüst davrandığı, karşılaşılabilecek herhangi bir sorunda müşterileri için çaba sarf edeceği, gereksinimlerin ve sorunların giderilmesinde işletmenin yeterli olduğuna dair müşterilerin inancı, işletmeye dair güveni oluşturmaktadır (Walter, Helfert ve Mueller, 2000: 3).

Güven, işletme ile müşteri arasındaki bağı güçlendirmekte ve işletmeye olan sadakatin oluşmasını desteklemektedir (Kalyoncuoğlu, 2017:389). Müşteriler ile güvene dayalı ilişkiler kurabilen, her bir müşteriye kişiselleştirilmiş ürünler sunabilen, müşteriyi odak noktasına koyan bir yaklaşım benimseyen ve müşterilerin diğer işletmelere kaymaması için değişim engelleri yaratabilen işletmeler müşteri sadakati oluşturabilirler (Selvi, 2007: 49). Tüketiciler, karşılaşacakları riskleri azaltmak amacıyla güven duyduğu işletme ve markalara 
yönelirler ve sonraki ihtiyaçlarında da aynı işletmeyi tercih etmeleri sonucunda söz konusu işletme ve markaya karşı sadakat kazanırlar (Gürbüz ve Doğan, 2013:240).

Bankacılık işlemleri açısından güven kavramı ele alındığında; müşterilerin daha temkinli hareket ettikleri gözlenmektedir. Müşterilerin bankaların kayıtlarında bulunan kişisel bilgileri, hesaplardaki mevduatları güven konusunda daha temkinli davranmalarına neden olmaktadır. Özellikle elektronik hizmetlerdeki altyapının güvenilir olması, son yıllarda artan siber dolandırıcılık gibi müşterileri madden tehdit edici unsurlar müşterilerin bankalarına olan sadakat düzeyleri üzerinde etkili olacağı düşünülmektedir.

Bağgllık: Bağlılık, müşterilerin pek çok uyarana maruz kalmasına karşın satın alma işlemlerini aynı işletmeden gerçekleştirmesi olarak tanımlanmaktadır (Matzler, Grabner-Krauter \& Bidmon, 2008:156).Bağlılık hizmetlere, işletmelere, ürün sınıflarına ve çeşitli etkinlere karşı geliştirilebilmekte ve dar anlamda bir ruh hali, tutumlar seti, inançlar, istekler vb. olarak ifade edilebilmektedir (Zineldin, 2006: 433). Küreselleşmenin yoğun olarak yaşandığı ve hızlı teknolojik gelişimlerin işletmeleri rekabet baskısı altına aldığı günümüzde işletmeler kendilerini terk etmeyecek bağlı müşterilere ihtiyaç duymaktadır (Karcıŏ̆lu Çelik, 2012: 64).

Bankacılık sektörü açısından ele alındığında bağlılık, mevcut müşterilerin rakiplerin tüm uygulamalarına ve baskılarına rağmen bankalarını terk etmemeleri olarak tanımlanabilir. Günümüzde yoğun rekabetin yaşandığı sektörlerden birisi olarak bankacılık sektörünün yeni müşterilere ihtiyacı olduğu gibi, mevcut müşterilerinin de kendilerini terk etmeyecek bağlı müşterilere ihtiyacı vardır. Bankalar mevcut müşterilerini kendilerine bağlamak için farklı uygulamalara yönelmektedirler. Örneğin, maaşını bankalarından almaya devam etmeleri durumunda hesap işletim ücretinden muafiyet, kendi banka müşterilerine yapılan para transferlerinin ücretsiz gerçekleştirilmesi, uygun koşullarda kredi vb. Bankalar bu uygulamalarla müşterilerini kendilerine bağlayarak, sadık müşteriler oluşturmaya çalışmaktadırlar.

Bu kapsamda bankaların faaliyetlerini sürdürebilmeleri, müşteri istek ve beklentilerini karşılayarak, rakipleri ile rekabet edebilmeleri, sahip oldukları ilişkisel ve teknolojik kaynakları etkin kullanmalarına ve bu kaynakları geliştirerek, doğru yönetmeleriyle sağlanabilecektir.

\section{Yöntem}

\subsection{Araştırmanın Modeli ve Hipotezleri}

Bu araştırma; ilişkisel ve teknolojik kaynakların e-sadakat üzerindeki etkilerinin incelenmesine yönelik olarak tarama modelinin bir çeşidi olan ilişkisel tarama modeli ile gerçekleştirilmiştir. İlişkisel tarama modeli bir ya da birden fazla değişken arasında ilişki belirlenebilmektedir (Karasar, 2012: 77). Araştırmanın şematik modeli şekil 1'de verilmiştir.

Araştırmanın modeli doğrultusunda araştırmada aşağıdaki hipotezler sorgulanmaktadır:

- Hı: Banka müşterilerinin bankalarının sunduğu çevrimdışı hizmetlere ilişkin kalite algıları e-sadakat düzeylerini etkilemektedir.

- $\mathrm{H}_{2}$ : Banka müşterilerinin bankalarının sunduğu e- hizmetlere ilişkin kalite algıları e-sadakat düzeylerini etkilemektedir.

- $\mathrm{H}_{2}$ : Banka müşterilerinin bankalarının sunduğu e- hizmetlere ilişkin memnuniyet algıları e-sadakat düzeylerini etkilemektedir.

- $\mathrm{H}_{4}$ : Banka müşterilerinin banka hizmetlerine ilişkin güvenilirlik algıları e-sadakat düzeylerini etkilemektedir.

- $\mathrm{H}_{5}$ : Banka müşterilerinin bankalarına duydukları bağlılık düzeyi e-sadakat düzeylerini etkilemektedir. 


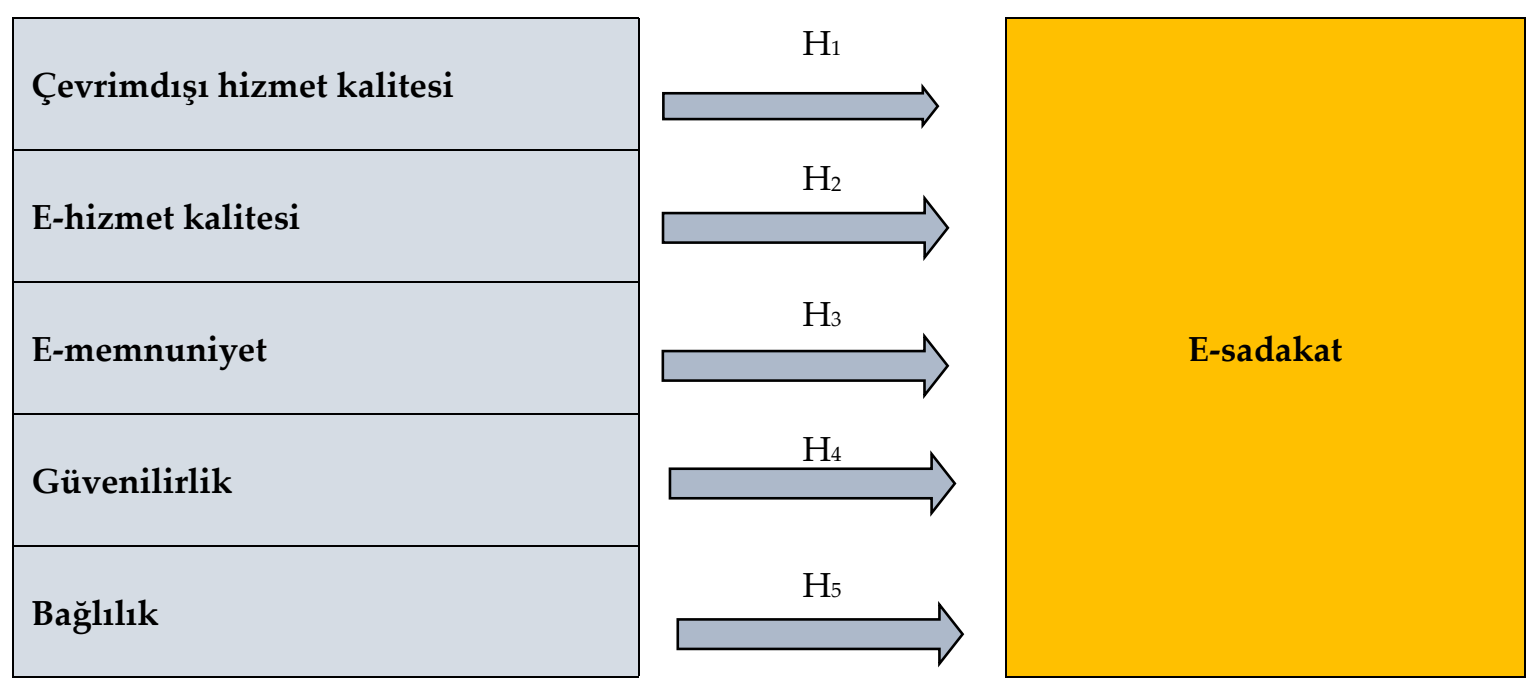

Şekil. Araştırmanın Modeli

\subsection{Evren ve Örneklemi}

Araştırmanın evrenini 2019 yılında Niğde ili merkez ilçede yer alan özel ve kamu bankalarından hizmet alan işletme yöneticileri oluşturmaktadır. Örneklemini ise evren içerisinde bulunan amaçlı örnekleme yöntemine göre belirlenmiş araştırmaya katılmayı gönüllü kabul eden 228 işletme yöneticisi oluşturmuştur.

\subsection{Veri Toplama Araçları}

Araştırmada veriler anket yöntemi ile toplanmıştır. Söz konusu anket formu iki bölümden oluşmaktadır. Birinci bölümde katılımcıların yaş, cinsiyet vb. tanımlayıcı özelliklerini belirlemeye yönelik çoktan seçmeli dört soru yer almaktadır. Anketin ikinci bölümünde (Kingshott vd., 2018) tarafından ilişkisel ve teknolojik kaynakların e-sadakat üzerinde etkisini incelemek için geliştirdikleri 6 boyutta 26 maddeden oluşan 5'li likert tipinde ölçek yer almaktadır. Tablo 1'de ölçekteki boyutlar, ölçekteki sıralarıyla yer alarak güvenirlik değerleri verilmiştir.

Tablo 1. Ölçekte Yer alan Boyutlar ve Güvenirlik Değerleri

\begin{tabular}{|l|l|c|}
\hline Faktörler & Madde sayısı & Güvenirlik değeri: Cronbach'a Alpha \\
\hline Çevrimdışı hizmet kalitesi & 3 & 0,950 \\
\hline E-hizmet kalitesi & 5 & 0,941 \\
\hline E-hizmetlerden memnuniyet & 4 & 0,933 \\
\hline Güvenilirlik & 6 & 0,944 \\
\hline Bağlllık & 5 & 0,906 \\
\hline E-sadakat & 3 & 0,899 \\
\hline Ölçeğin tamamı & 26 & 0,916 \\
\hline
\end{tabular}

\subsection{Verilerin İstatistiksel Analizi}

Araştırmada veriler SPSS 22.0 istatistik programı aracılığıyla değerlendirilmiştir. Katılımcıların tanımlayıcı özelliklerinin incelenmesinde frekans ve yüzde analizlerinden, ilişkisel incelenmesinde ortalama ve standart sapma istatistiklerinden faydalanılmıştır. Ölçek boyutlarının aldığı puanlar 1 ile 5 arasında değerlendirilmektedir. Dağılım aralığının hesaplanması amacıyla, Dağılım aralığı=En büyük değer- En küçük değer/ Derece sayısı formülü kullanılmıştır. Bu aralık 4 puanlık genişliğe sahiptir. Bu genişlik beş eşit genişliğe bölünerek 1.00- 1.79 arası "çok düşük", 1.80- 2.59 arası "düşük", 2.60- 3.39 "arası orta", 3.40-4.19 arası yüksek, 4.20-5.00 arası çok yüksek olarak sınır değerleri belirlenmiş ve bulgular yorumlanmıştır (Sümbüloğlu, 1993: 9). İlişkisel ve teknolojik kaynaklar ile e-sadakat arasındaki ilişki pearson korelasyon analizi ile ilişkisel ve teknolojik kaynakların e-sadakat üzerindeki etkisi regresyon analizi ile incelenmiştir. Ayrıca katılımcıların bankalarının hizmetlerine ilişkin algıladıkları çevrimdışı hizmet kalitesi, e-hizmet kalitesi, e-hizmetlerden memnuniyet, güvenilirlik ve bağlılık (ilişkisel ve teknolojik kaynaklar) ile e- sadakat düzeylerinin hizmet 


\section{H. E. Kaplan 12/2 (2020) 1334-1346}

aldıkları bankanın sahiplik durumuna göre (Özel ve Kamu) farklılaşma durumu bağımsız gruplar t- testi ile incelenmiştir. Anlamlılık 0, 05 düzeyinde sınanarak yorumlanmıştır.

\section{Bulgular}

Araştırmaya katılan banka müşterilerinin tanımlayıcı bilgilerine dair veriler Tablo 2' de sunulmuştur.

Tablo 2. Katılımcıların Tanımlayıcı Özellikleri

\begin{tabular}{|c|c|c|}
\hline Gruplar & $\mathbf{n}$ & $\%$ \\
\hline \multicolumn{3}{|l|}{ Yaş } \\
\hline $26-30$ & 31 & 13,6 \\
\hline $31-35$ & 52 & 22,8 \\
\hline $36-40$ & 37 & 16,2 \\
\hline $41-45$ & 40 & 17,5 \\
\hline $46-50$ & 38 & 16,7 \\
\hline 51 ve üzeri & 30 & 13,2 \\
\hline \multicolumn{3}{|l|}{ Cinsiyet } \\
\hline Kadın & 156 & 68,4 \\
\hline Erkek & 72 & 31,6 \\
\hline \multicolumn{3}{|c|}{ Bankayla Çalışma Süresi } \\
\hline $0-1 Y_{1}$ & 47 & 20,6 \\
\hline $1-5 Y_{11}$ & 80 & 35,1 \\
\hline 6-10 Yil & 64 & 28,1 \\
\hline 11-15 Yil & 37 & 16,2 \\
\hline \multicolumn{3}{|c|}{ Bankanın Sahiplik Yapısı } \\
\hline Kamu & 174 & 76,3 \\
\hline Özel & 54 & 23,7 \\
\hline
\end{tabular}

Tablo 2' deki verilere bakıldığında araştırmaya katılan banka müşterileri yaşlarına göre 31'i $(\% 13,6)$ 26-30 yaş, 52'si (\%22,8) 31-35 yaş, 37'si (\%16,2) 36-40yaş, 40' ' (\%17,5) 41-45 yaş, 38'i (\%16,7) 46-50 yaş 30'u (\%13,2) 51 ve üzeri yaşlarda bulunduğu, 156'sının(\%68,4) kadın, 72'sinin (\%31,6) erkek olduğu görülmektedir. Katılımcıların 47'si (\%20,6) 0-1 yıl, 80'i (\%35,1) 1-5 yıl, 64'ü (\%28,1) 6-10 yıl, 37'si $(\% 16,2)$ 11-15 yıldır bankalarıyla çalışma süresine sahip olup, 174'ü $(\% 76,3)$ kamu, 54'ü (\%23,7) özel bankalardan hizmet almaktadır.

Tablo 3'de banka müşterilerinin ilişkisel ve teknolojik kaynaklara ilişkin algı ve e-sadakat düzeylerine yönelik veriler yer almaktadir.

Tablo 3. Katılımcıların Banka Hizmetlerine İlişkin İlişkisel ve Teknolojik Kaynaklar Algıları ve E-Sadakat Düzeyleri

\begin{tabular}{|l|c|c|c|c|c|}
\hline & N & Ort & Ss & Min. & Max. \\
\hline Çevrimdışı Hizmet Kalitesi & 228 & 3,699 & 1,055 & 1,000 & 5,000 \\
\hline Elektronik Hizmet Kalitesi & 228 & 3,781 & 1,073 & 1,000 & 5,000 \\
\hline Elektronik Memnuniyet & 228 & 3,700 & 1,095 & 1,000 & 5,000 \\
\hline Güvenilirlik & 228 & 3,756 & 1,111 & 1,000 & 5,000 \\
\hline Bağlllık & 228 & 3,723 & 1,109 & 1,000 & 5,000 \\
\hline E-Sadakat & 228 & 3,752 & 1,143 & 1,000 & 5,000 \\
\hline
\end{tabular}

Tablo 3'e bakıldığında müşterilerin ilişkisel ve teknolojik kaynaklar ölçeğinde yer alan "Çevrimdışı Hizmet Kalitesi" ortalamasının 3,699 $\pm 1,055$, "Elektronik Hizmet Kalitesi" ortalamasının 3,781 $\pm 1,073$ "elektronik memnuniyet" ortalamasının 3,700 $\pm 1,095$ "güvenilirlik" ortalamasının yüksek 3,756 $\pm 1,111$ "bağlllık" ortalamasının 3,723 $\pm 1,109$ sayısal değer aldığı ve "elektronik sadakat" düzeylerinin ortalamasının 3,752 $\pm 1,143$ olduğu görülmektedir. 
Tablo 4'te banka müşterilerinin ilişkisel ve teknolojik kaynaklara ilişkin algıları ile e-sadakat düzeyleri arasındaki ilişkileri belirlemek için yapılan korelasyon analizi verileri yer almaktadır.

Tablo 4. Korelasyon Analizi

\begin{tabular}{|l|l|l|l|l|c|c|}
\hline & $\begin{array}{l}\text { Çevrimdışı Hizmet } \\
\text { Kalitesi }\end{array}$ & $\begin{array}{l}\text { Elektronik Hizmet } \\
\text { Kalitesi }\end{array}$ & $\begin{array}{l}\text { Elektronik } \\
\text { Memnuniyet }\end{array}$ & Güvenilirlik & Bağlılık \\
\hline $\begin{array}{l}\text { Elektronik } \\
\text { Sadakat }\end{array}$ & $\mathrm{r}$ & $0,909^{* *}$ & $0,895^{* *}$ & $0,895^{* *}$ & $0,936^{* *}$ & $0,971^{* *}$ \\
\cline { 2 - 6 } & $\mathrm{p}$ & 0,000 & 0,000 & 0,000 & 0,000 & 0,000 \\
\hline
\end{tabular}

${ }^{*}<0,05 ;{ }^{* *}<0,01$

Tablo 4'teki banka müşterilerinin ilişkisel ve teknolojik kaynaklar "çevrimdışı hizmet kalitesi, elektronik hizmet kalitesi, elektronik memnuniyet, güvenilirlik, bağlllık" ile elektronik sadakat arasındaki korelasyon analizleri incelendiğinde;

- Elektronik sadakat ile çevrimdışı hizmet kalitesi arasında $r=0.909$ pozitif $(\mathrm{p}=0,000<0.05)$,

- Elektronik sadakat ile elektronik hizmet kalitesi arasında $\mathrm{r}=0.895$ pozitif $(\mathrm{p}=0,000<0.05)$,

- Elektronik sadakat ile elektronik memnuniyet arasında $\mathrm{r}=0.895$ pozitif $(\mathrm{p}=0,000<0.05)$,

- Elektronik sadakat ile güven arasında $\mathrm{r}=0.936$ pozitif $(\mathrm{p}=0,000<0.05)$,

- Elektronik sadakat ile bağlllık arasında $\mathrm{r}=0.971$ pozitif $(\mathrm{p}=0,000<0.05)$ ilişki olduğu görülmektedir.

Bu sonuçlar ilişkisel ve teknolojik kaynaklar ile e-sadakat arasında çift yönlü ilişkileri göstermektedir. Esadakatteki azalma veya artmanın aynı doğrultuda ilişkisel ve teknolojik kaynaklara yönelik algıda da azalma veya artmaya neden olacağını göstermektedir.

Tablo 5'te ilişkisel ve teknolojik kaynakların e-sadakat üzerindeki etkisini incelemeye yönelik yapılan regresyon analizi verileri yer almaktadır.

Tablo 5. İlişkisel ve Teknolojik Kaynakların Elektronik Sadakat Üzerine Etkisi

\begin{tabular}{|c|c|c|c|c|c|c|c|}
\hline Bağımlı Değişken & Bağımsız Değişken & B & $\mathbf{t}$ & $\mathbf{p}$ & $\mathbf{F}$ & Model (p) & $\mathbf{R}^{2}$ \\
\hline \multirow{6}{*}{ Elektronik Sadakat } & Sabit & $-0,027$ & $-0,432$ & 0,666 & \multirow{6}{*}{884,379} & \multirow{6}{*}{0,000} & \multirow{6}{*}{0,951} \\
\hline & Çevrimdışı Hizmet Kalitesi & 0,297 & 5,358 & 0,000 & & & \\
\hline & E-Hizmet Kalitesi & $-0,074$ & $-1,201$ & 0,231 & & & \\
\hline & E-Memnuniyet & 0,247 & $-4,694$ & 0,000 & & & \\
\hline & Güvenilirlik & 0,093 & 1,433 & 0,153 & & & \\
\hline & Bağlllık & 0,947 & 15,061 & 0,000 & & & \\
\hline
\end{tabular}

İlişkisel ve teknolojik kaynakların (Çevrimdışı hizmet kalitesi, elektronik hizmet kalitesi, elektronik memnuniyet, güvenilirlik, bağlılık) elektronik sadakat üzerindeki etkisini belirlemek üzere yapılan regresyon analizi anlamlı bulunmuştur ( $\mathrm{F}=884,379 ; \mathrm{p}=0,000<0.05)$. Elektronik sadakat düzeyindeki toplam değişim \%95,1 oranında çevrimdışı hizmet kalitesi, elektronik hizmet kalitesi, elektronik memnuniyet, güven, bağlılık tarafından açıklanmaktadır $\left(\mathrm{R}^{2}=0,951\right)$. Çevrimdışı hizmet kalitesi elektronik sadakat düzeyini arttırmaktadır $(ß=0,297)$. Elektronik hizmet kalitesi elektronik sadakat düzeyini etkilememektedir $(\mathrm{p}=0.231>0.05)$. Elektronik memnuniyet elektronik sadakat düzeyini artırmaktadır $(\Omega=-0,247)$. Güven elektronik sadakat düzeyini etkilememektedir $(p=0.153>0.05)$. Bağlllık elektronik sadakat düzeyini arttırmaktadır $(ß=0,947)$. Araştırmanın Sonuç modeli Şekil 2'de verilmiştir.

Araştırmanın sonuç modelinde özetlendiği gibi, araştırmanın başında belirtilen 5 hipotezden 3'ü kabul edilirken, 2'si reddedilmiştir. Bu durumda

- “Hı: Banka müşterilerinin bankalarının sunduğu çevrimdışı hizmetlere ilişkin kalite algıları e-sadakat düzeylerini etkilemektedir" doğrulanarak kabul edilmiştir.

- “ $\mathrm{H}_{2}$ : Banka müşterilerinin bankalarının sunduğu e- hizmetlere ilişkin kalite algıları e-sadakat düzeylerini etkilemektedir, doğrulanamayarak reddedilmiştir. 
- “H3: Banka müşterilerinin bankalarının sunduğu e- hizmetlere ilişkin memnuniyet algıları e-sadakat düzeylerini etkilemektedir" doğrulanarak kabul edilmiştir.

- “H4: Banka müşterilerinin banka hizmetlerine ilişkin güvenilirlik algıları e-sadakat düzeylerini etkilemektedir" doğrulanamayarak reddedilmiştir.

- "H5: Banka müşterilerinin bankalarına duydukları bağlılık düzeyi e-sadakat düzeylerini etkilemektedir" doğrulanarak kabul edilmiştir.

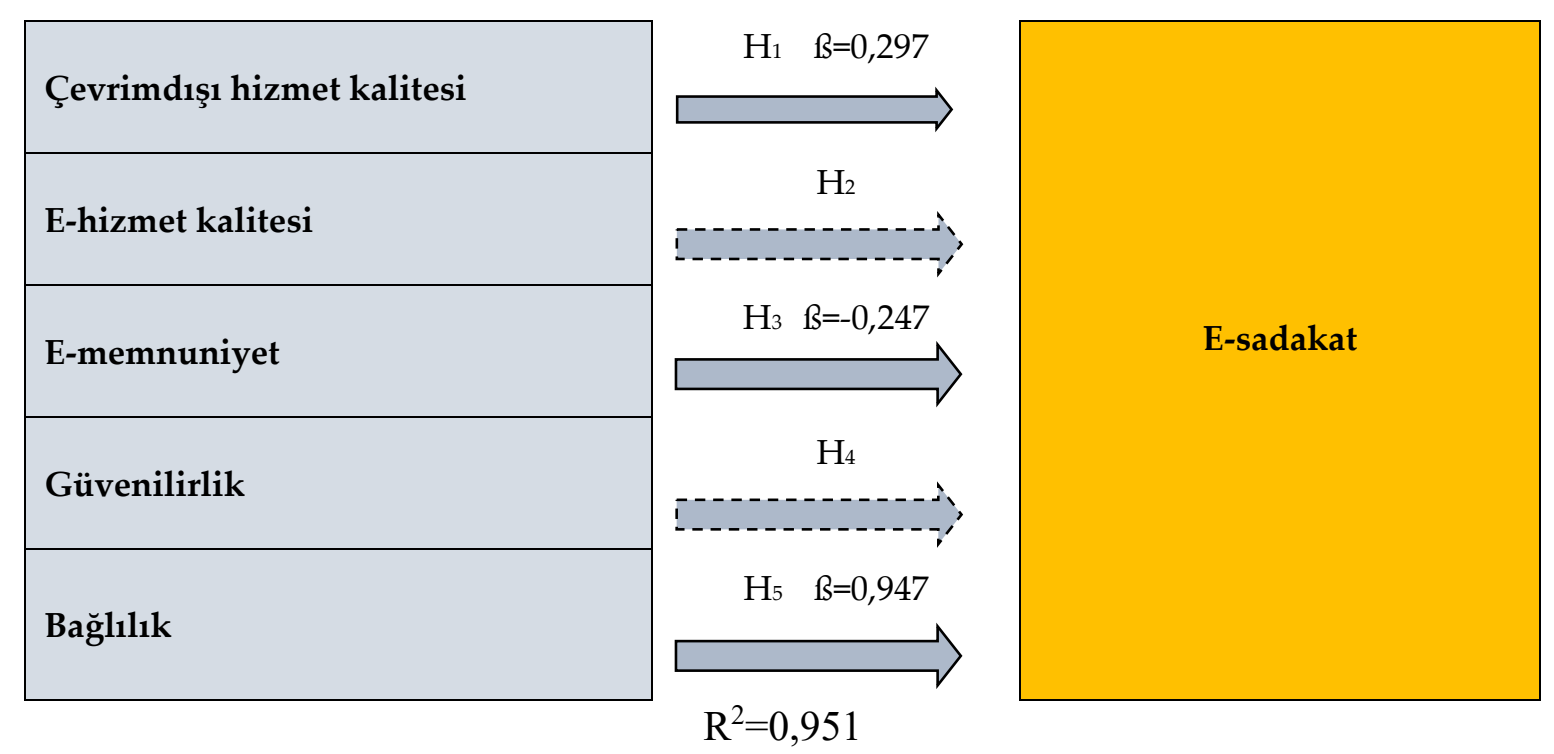

Şekil 2. Araştırmanın Sonuç Modeli

Tablo 6'da katılımcıların hizmet aldıkları bankanın sahiplik yapısına göre ilişkisel kaynaklara yönelik algı ve e sadakat düzeylerinin farklılaşma durumunu incelemek için yapılan bağımsız gruplar t-testi sonuçları yer almaktadir.

Tablo 6. Katılımcıların Hizmet Aldıkları Bankanın Sahiplik Yapısına Göre İlişkisel Kaynaklara Yönelik Algı ve E- Sadakat Düzeylerinin Farklılaşma Durumu

\begin{tabular}{|c|c|c|c|c|c|c|c|}
\hline & Grup & $\mathbf{N}$ & Ort & Ss & $\mathbf{t}$ & sd & $\mathbf{p}$ \\
\hline \multirow{2}{*}{ Çevrimdışı Hizmet Kalitesi } & Kamu & 174 & 3,686 & 1,024 & \multirow{2}{*}{$-0,333$} & \multirow{2}{*}{226} & \multirow{2}{*}{0,739} \\
\hline & Özel & 54 & 3,741 & 1,160 & & & \\
\hline \multirow{2}{*}{ Elektronik Hizmet Kalitesi } & Kamu & 174 & 3,800 & 1,030 & \multirow{2}{*}{0,487} & \multirow{2}{*}{226} & \multirow{2}{*}{0,656} \\
\hline & Özel & 54 & 3,719 & 1,209 & & & \\
\hline \multirow{2}{*}{ Elektronik Memnuniyet } & Kamu & 174 & 3,753 & 1,063 & \multirow{2}{*}{1,322} & \multirow{2}{*}{226} & \multirow{2}{*}{0,187} \\
\hline & Özel & 54 & 3,528 & 1,186 & & & \\
\hline \multirow{2}{*}{ Güven } & Kamu & 174 & 3,805 & 1,079 & \multirow{2}{*}{1,191} & \multirow{2}{*}{226} & \multirow{2}{*}{0,235} \\
\hline & Özel & 54 & 3,599 & 1,206 & & & \\
\hline \multirow{2}{*}{ Bağllık } & Kamu & 174 & 3,766 & 1,079 & \multirow{2}{*}{1,044} & \multirow{2}{*}{226} & \multirow{2}{*}{0,298} \\
\hline & Özel & 54 & 3,585 & 1,201 & & & \\
\hline \multirow{2}{*}{ Elektronik Sadakat } & Kamu & 174 & 3,782 & 1,125 & \multirow{2}{*}{0,714} & \multirow{2}{*}{226} & \multirow{2}{*}{0,476} \\
\hline & Özel & 54 & 3,654 & 1,203 & & & \\
\hline
\end{tabular}

Tablo 6' daki verilere bakıldığında; banka müşterilerinin çevrimdışı hizmet kalitesi, elektronik hizmet kalitesi, elektronik memnuniyet, güven, bağlılık algıları ve elektronik sadakat düzeyleri hizmet aldıkları bankanın sahiplik yapısına göre farklılık göstermemektedir $(p>0,05)$. Bu sonuç özel ve kamu bankalarının benzer düzeyde ilişkisel ve teknolojik kaynaklara sahip olduklarını ve müşterilerin de elektronik hizmet aldığı banka ister özel olsun ister kamu bankası olsun sadakatle bağlı olduklarını göstermektedir. Aynı zamanda özel ve 
kamu bankalarının verdikleri hizmet ve kalite açısından benzer niteliklere sahip olduğunu da ifade etmektedir.

Literatürde konu ile ilgili yapılan araştırmalara bakıldığında, kamu ve özel bankalarının karşılaştırılmalı olarak incelendiği araştırmalarda genellikle finansal performansı değişken olarak ele aldıkları, ilişkisel ve teknolojik kaynakları bu araştırmadaki gibi bir bütün olarak sadece Kingshott vd.,( 2018)'nin inceledikleri görülmektedir. Adı geçen araştırmada da ilişkisel ve teknolojik kaynaklar, birbirini destekleyen bir bütün olarak ele alınmış ve benzer sonuçlara ulaşılmıştır.

\section{Sonuç}

İlişkisel ve teknolojik kaynakların e-sadakat üzerindeki etkilerini özel ve kamu banka çalışanları üzerinde incelemek amacıyla gerçekleştirilen araştırmaya 226 ticari banka müşterisi katılmıştır. Araştırmada bankaların ilişkisel ve teknolojik kaynakları; çevrimdışı hizmet kalitesi, e-hizmet kalitesi, e-memnuniyet, güvenilirlik ve bağlılık olarak ele alınmıştır. 5 üzerinden yapılan değerlendirme sonucunda katılımcıların bankalarından aldıkları çevrimdışı hizmetlere ilişkin kalite algılarının ortalamalarının 3,699, e-hizmet kalitesi algılarının 3,781, e-memnuniyet algılarının 3,700, güvenilirlik algılarının 3,756 ve bağlllık algılarının 3,723 düzeyinde olduğu saptanmıştır. Katılımcıların e-sadakat düzeylerinin ortalaması ise 3,752'dir. Buradan banka müşterilerinin bankalarının sunduğu çevrimdışı ve e-hizmetlerine ilişkin kalite algılarının yüksek olduğu, aldıkları hizmetten yüksek düzeyde memnuniyet duydukları, hizmetlerin yüksek düzeyde güvenilir olduğunu algıladıkları ve bankalarına yüksek düzeyde bağlı oldukları saptanmıştır. Aynı doğrultuda müşteriler, bankalarına yüksek düzeyde sadakat duymaktadırlar.

Bilgi ve iletişim teknolojilerinde yaşanan gelişmelerden en fazla etkilenen sektörlerden birisi bankacılıktır. Yaşanan gelişmeler doğrultusunda bankalar ilişkisel ve teknolojik kaynaklarını geliştirerek çeşitlendirmiş, elektronik altyapılarını da güçlendirmişlerdir. Bu durum müşterilerin e-bankacılığın ilk zamanlarındaki ebankacılığa duyulan güvensizlik hissinin azalmasına sağlarken, hizmet kalite algılarının, memnuniyet, bağlılık ve sadakat düzeylerinin araştırma sonuçlarından da gözlendiği üzere artmasına neden olmuştur.

Araştırmada banka müşterilerinin ilişkisel ve teknolojik kaynaklara ilişkin algıları ile e-sadakat düzeyleri arasındaki ilişkileri belirlemek için korelasyon analizi yapılmıştır. Analiz sonucunda, e-sadakat ile çevrimdışı hizmet kalitesi, e-hizmet kalitesi, e-memnuniyet, güvenilirlik ve bağlllık arasında yüksek düzeyde pozitif yönlü 0,01 düzeyinde karşlıklı anlamlı ilişkiler olduğu saptanmıştır. Buradan ilişkisel ve teknolojik kaynaklar kapsamında ele alınan bir değişkene ilişkin artma veya azalmanın aynı doğrultuda e-sadakat düzeylerini artıracağı ya da azaltacağı sonucuna ulaşılmıştır. Benzer sonuçlar Kingshott vd.,( 2018) Yeni Zelanda'da işletme bankacılığ 1 müşterileri üzerinde gerçekleştirdikleri araştırmada da ulaşılmıştır. Buradan işletme bankacıllı̆ı müşterilerinin ilişkisel ve teknolojik kaynaklar ile e-sadakat düzeyleri arasındaki ilişkilerin dünyadaki farklı ülkelerde de benzer sonuçları ortaya koyabileceği görülmekte, lakin genelleme yapabilmek için farklı ülkelerdeki işletme bankacılığı müşterileri üzerinde araştırmaların yapılması gerekli görülmektedir.

Kamu ve özel bankalar ilişkisel ve teknolojik kaynaklarına yaptıkları yatırımların sonucuna müşterilerden sadakat olarak geri bildirim alabilmektedirler. Sadık müşterilere sahip olmak bankanın mevcut varlığını sürdürebilme kapasitesi olarak değerlendirilebilir. Ancak rekabette ön plana çımak istiyorlarsa yeni müşteriler kazanmaları gerekmektedir. Bu da yine ilişkisel ve teknolojik kaynaklarını geliştirmeleri ile sağlanabilecektir.

Araştırmada ilişkisel ve teknolojik kaynakların e-sadakat üzerindeki etkisini incelemek için regresyon analizi yapılmıştır. Analiz sonucunda; araştırmada ele alınan ilişkisel ve teknolojik kaynaklar kapsamında çevrimdışı hizmet kalitesi, e-hizmet kalitesi, e-memnuniyet, güvenilirlik ve bağlllı̆̆ın, müşterilerin sadakati üzerinde etkisini belirlemek için kurulan regresyon modelinin istatistiksel olarak anlamlı olduğu belirlenmiştir. Esadakati çevrimdışı hizmet kalitesi, e-memnuniyet ve bağlılık olumlu düzeyde etkilerken, e-hizmet kalitesi ve güvenilirlik istatistiksel olarak etkilememektedir. Bu sonucun ortaya çıkmasında birbirine yakın olan bu değişkenlerin ayrı ayrı ele alınmasının etkisi bulunmaktadır. Çünkü bütünsel olarak bakıldığında, ilişkisel ve teknolojik kaynakların (çevrimdışı hizmet kalitesi, e-hizmet kalitesi, e-memnuniyet, güvenilirlik ve bağlllık) müşteri sadakatini \%95 düzeyinde açıkladığı saptanmıştır. Diğer bir ifadeyle, e-sadakat neredeyse ilişkisel ve teknolojik kaynakların toplamından oluşmaktadır. 


\section{H. E. Kaplan 12/2 (2020) 1334-1346}

Araştırmada ayrıca araştırmaya katılan banka müşterilerinin hizmet aldıkları bankanın sahiplik yapısına göre ilişkisel kaynaklara yönelik alg1 ve e- sadakat düzeylerinin farklılaşma durumu da incelenmiş, kamu veya özel bankalardan hizmet alan müşterilerin bankaların ilişkisel ve teknolojik kaynaklarına ilişkin algılarının ve esadakat düzeylerinin istatistiksel olarak farklılık göstermediği, diğer bir ifade ile benzer düzeyde olduğu saptanmıştır. Buradan kamu ve özel bankaların ilişkisel ve teknolojik kaynaklardan benzer şekillerde ve benzer düzeylerde kullandıkları, bu durumun da müşteri algılarına doğrudan yansıdığı söylenebilir. Gerek özel banka gerekse kamu bankalarının müşterileri bankalarına oldukça sadıktırlar. Bankalar mevcut müşterileri ile aynı doğrultuda ilişkiler kurmaya devam ederlerse müşteri kaybı yaşamayacaklardır, ancak rakipler bu hizmetleri geliştirip kendilerinden öne geçmeleri durumunda müşteri kaybı yaşama riski ile karşılaşabilirler. Bu durumla karşılaşmamak için ilişkisel ve teknolojik kaynaklarını dinamik tutarak sürekli güncelleme ve geliştirme çabası içerisinde olmalıdırlar.

Bu araştırma Niğde il merkezinde bulunan kamu ve özel bankaların araştırmaya katılmayı gönüllü kabul eden 226 ticari müşterisi ile sınırlıdır. Araştırma sonuçlarından genelleme yapabilmek için, daha geniş örneklemler üzerinde araştırmalar gerçekleştirilebilir. İlişkisel ve teknolojik kaynakların birbirini tamamlayan bir bütün olarak ele alındığı, e-sadakat üzerindeki etkileri çevrimiçi olarak hizmet veren online mağazalar vb. alanlarda da yapilabilir.

\section{KAYNAKÇA}

Arslan, S. ve Atalık, Ö. (2016). Sosyal Medya sitelerindeki e- sadakat ve Türkiye'de faaliyet gösteren havayolu işletmelerinde bir uygulama, Niğde Üniversitesi İktisadi ve İdari Bilimler Fakültesi Dergisi, 9, 1-20.

Başaran, B. ve Çelik, H. (2008). E-hizmet müşterileri arasında e-hizmet kalite boyutlarını algılamada oluşan farklılıkların incelenmesi, Ç.Ü. Sosyal Bilimler Enstitüsü Dergisi, 17(3), 47-62.

Bayram, A. T. ve Şahbaz, P. (2017). E-hizmet uygulamalarında kalite algısı, memnuniyet ve sadakat tutumlarının demografik özelliklere göre incelenmesi: seyahat acentaları müşterileri örneği, Journal of Tourism and Gastronomy Studies, 5(1), 60-75.

Berry, L. L. (2000). Cultivating service brand equity, Journal of the Academy of Marketing Science, 28(1), 128-137. https://doi.org/10.1177/0092070300281012

Chinomona, R., Masinge, G. and Sandada, M. (2014). The influence of e-service quality on customer perceived value, customer satisfaction and loyalty in South Africa, Mediterranean Journal of Social Sciences, 5(9), 331-341.

Demir, Ş. Ş. (2012). Avrupa müşteri memnuniyeti endeksi modeli: uluslararası otel işletmelerine yönelik bir Uygulama, Uluslararası İnsan Bilimleri Dergisi, 9(1), 672-695.

Demirgüneş. (2016). İnternet alışverişlerinde hedonik ve faydacı değer algılarının davranışsal sonuçları: esadakat ve ağızdan ağıza iletişim, Kastamonu Üniveritesi İ.I. B.F Dergisi, (13), 246-269.

Devebakan, N. and Aksaraylı, M. (2003). Sağlık İşletmelerinde algılanan hizmet kalitesinin ölçümünde SERVQUAL skorlarının kullanımı ve Özel Altınordu Hastanesi, Dokuz Eylül Üniversitesi Sosyal Bilimler Enstitüsü Dergisi, 5(1), 38-54.

Duman, T. (2003). Richard L. Oliver'ın tüketici memnuniyeti (customer satisfaction) ve tüketici değer algısı (customer value) kavramları hakkındaki görüşleri: teorik bir karşlaştırma, Dokuz Eylül Üniversitesi Sosyal Bilimler Enstitüsü Dergisi, 5(2), 45-56.

Eren, S. ve Erge, A. (2012). Marka güveni, marka memnuniyeti ve müşteri değerinin tüketicilerin marka sadakati üzerine etkisi, Journal of Yasar University, 26(7), 4445-4482.

Faiz, E. (2018). Online seyahat alişverişlerinin hizmet kalitesinin e-memnuniyet ve e-sadakat üzerindeki etkisi, Elektronik Sosyal Bilimler Dergisi, 17(68), 1675-1690.

Fournier, S. (1998). Consumers and their brands: developing relationship theory in consumer research, Journal of Consumer Research, 24(4), 343-373. https://doi.org/10.1086/209515

Giese, J. and Cote, J. (2002). Defining consumer satisfaction, Academy of Marketing Science Review, 4(1), 1-24.

Gürbüz, A. ve Doğan, M. (2013). Tüketicilerin markaya duyduğu güven ve marka bağlıllı̆̆ ilişkisi, Uluslararası Yönetim İktisat ve İşletme Dergisi, 19, 240-258. 


\section{H. E. Kaplan 12/2 (2020) 1334-1346}

Kalyoncuoğlu, S. (2017). Markaya duyulan güven ile marka sadakati ilişkisinde marka aşkının aracılık rolü: starbucks markası üzerine bir araştırma, Journal of Tourism and Gastronomy Studies, 5(4), 393-402.

Karasar, N. (2012). Bilimsel Araştırma Yöntemleri (23. bs). Ankara, Nobel Yayınları.

Kingshott, R. P. J., Sharma, P. and Chung, H. F. L. (2018). The impact of relational versus technological resources on e-loyalty: A comparative study between local, national and foreign branded banks, Industrial Marketing Management, 72, 48-58. https://doi.org/10.1016/j.indmarman.2018.02.011

Kotler, P. and Armstrong, G. (2012). Principles of Marketing. (15 th edt.). Pearson Inc., Prentice Hall.

Lee, G. G. and Lin, H. F. (2005). Customer perceptions of e-service quality in online shopping, International Journal of Retail and Distribution Management, 33(2), 161-176.

Ltifi, M. ve Gharbi, J.E. (2012). E-satisfaction and e-loyalty of consumers shopping online, The Journal of Internet Banking and Commerce, 17(1), 1-20.

Matzler, K., Grabner-Krauter, S. and Bidmon, S. (2008). Risk aversion and brand loyalty: the mediating role of brand trust and brand affect, Journal of Product and Brand Management, 17(3), 154-162.

Mikhaylichenko, K. (2015). Finansal hizmetlerin küreselleşmesine katkı açısından elektronik bankacılık. (Yayımlanmamış yüksek lisans tezi). Marmara Üniversitesi Sosyal Bilimler Enstitüsü, İstanbul.

Nasır, S. ve Nasır, A. (2008). Hizmet Kalitesi, Çatı, K. ve Baydaş, A. (Ed.), Hizmet Pazarlaması ve Hizmet Kalitesi Ankara, Asil Yayın Dağıtım Ltd. Şti., 237-251.

Nguyen, N., Leclerc, A. and Leblanc, G. (2013). The mediating role of customer trust on customer loyalty, Journal of Service Science and Management, 6, 96-109. https://doi.org/10.4236/jssm.2013.61010

Öztürk, A. S. (2013). Hizmet Pazarlaması, Eskişehir, Bursa Yayınları.

Parasuraman, A. P., Zeithaml, V. and Malhotra, A. (2005). E-S-qual: A multiple-1tem scale for assessing electronic service quality, Journal of Service Research, 7(3), 213-233. https://doi.org/10.1177/1094670504271156

Pratminingsih, S. A., Lipuringtyas, C. and Rimenta, T. (2013). Factors influencing customer loyalty toward online shopping, International Journal of Trade, Economics and Finance, 4(3), 104-110.

Sağlam Arı, G. ve Tunçay, A. (2010). Yöneticiye duyulan güven ve tükenmişlik arasındaki ilişkiler: Ankara'daki devlet hastanelerinde çalışan idari personel üzerinde bir araştırma, Atatürk Üniversitesi İktisadi ve İdari Bilimler Dergisi, 24(4), 113-135.

Selvi, M. S. (2007). Müşteri Sadakati, Ankara, Detay Yayıncılık.

Sümbüloğlu, K. (1993). Biyoistatistik, Ankara, Özdemir Yayıncılık.

Toufaily, E., Ricard, L. and Perrien, J. (2013). Customer loyalty to a commercial website: Descriptive metaanalysis of the empirical literature and proposal of an integrative model, Journal of Business Research, 66(9), 1436-1447. https://doi.org/10.1016/j.jbusres.2012.05.011

Walter, A., Helfert, G. and Mueller, T. (2000). The Impact of Satisfaction, Trust, and Relationship Value on Commitment: Theoretical Considerations and Empirical Results, UK., University of Bath, 1-18.

Yapraklı, T. Ş. ve Yılmaz, M. K. (2008). İnternet bankacıllğı hizmeti kullanıcılarının hizmet kalitesi algılarının tatmin ve bağlllık düzeyleri üzerindeki etkisi: akademik personel üzerinde bir uygulama, Marmara Üniversitesi İ.̇.B.F Dergisi, 24(1), 137-161.

Zeithaml, V. A. (2000). Service quality, profitability, and the economic worth of customers: What we know and what we need to learn, Journal of the Academy of Marketing Science, 28 (1), 67-85. https://doi.org/10.1177/0092070300281007

Zineldin, M. (2006). The royalty of loyalty: CRM, quality and retention, Journal of Consumer Marketing, 23 (7), 430-437. https://doi.org/10.1108/07363760610712975. 